\title{
NARASTAJĄCA DOKUMENTACJA ELEKTRONICZNA WYTWARZANA WŚRÓD PRACOWNIKÓW NAUKOWYCH
}

\section{Słowa kluczowe}

dokumentacja elektroniczna; dokumenty elektroniczne; dokumentacja uczonych

\section{Keywords}

electronic records; electronic documents; records of scientists

\section{Streszczenie}

We współczesnym świecie technologia jest nieodzownym elementem zarówno w sferze prywatnej, jak i służbowej. I mimo że nie przywiązujemy w życiu codziennym do tego dużej wagi, rozwój technologiczny pochłonął ludzi i przypomina o tym na każdym kroku. W obliczu dynamicznie rozwijającej się cyfryzacji powstała nowa forma dokumentu - dokument elektroniczny. W badaniach zajęto się problematyką narastającej dokumentacji elektronicznej wśród pracowników naukowych pracujących na Uniwersytecie Mikołaja Kopernika w Toruniu. Analiza przeprowadzonych ankiet i wywiadów stała się podstawą tezy, że pracownicy naukowi decydują się na korzystanie

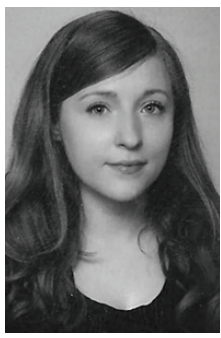

Monika Weiss, licencjat archiwistyki i zarządzania dokumentacją na Uniwersytecie Mikołaja Kopernika w Toruniu. Obecnie studentka II r. studiów magisterskich na UMK. Interesuje się problematyką dokumentacji elektronicznej oraz jej narastania w spuściznach archiwalnych. Bardzo lubi słuchać muzyki, gotować, podróżować i czytać. Tematem pracy licencjackiej napisanej pod kierunkiem dr hab. Waldemara Chorążyczewskiego, prof. UMK, była „Dokumentacja elektroniczna wytwarzana przez pracowników naukowych w świetle badań ankietowych na Uniwersytecie Mikołaja Kopernika w Toruniu". Email: monika.weiss0@gmail.com. 
z e-dokumentu częściej niż z dokumentacji analogowej. Elastyczność i dostępność tego rodzaju dokumentów zaczyna być jednak ogromnym problem w kwestii tworzących się w ten sposób spuścizn, które w przyszłości będą archiwizowane, być może w większości mając już postać dokumentacji elektronicznej.

1D) ynamiczny rozwój cyfryzacji oraz wprowadzenie do administracji nowego pojęcia, jakim jest dokument elektroniczny, zapoczątkował szereg badań na ten temat wśród pracowników naukowych. Jednak głównym powodem inspirującym do podjęcia tej problematyki były konferencje prowadzone przez Wydział Nauk Historycznych Uniwersytetu Mikołaja Kopernika w Toruniu (UMK) przy współpracy z Narodowym Archiwum Cyfrowym.

Celem przeprowadzanych ankiet było sprawdzenie, jak nową dokumentację odbierają naukowcy. Badania oscylowały wokół pytań: Czym jest dokument elektroniczny według pracowników naukowych? Czy go wytwarzają? Ponadto istotny był wiek i dyscyplina, w jakiej specjalizowała się osoba odpowiadająca. Zakres badań ograniczał się do osób pracujących na UMK.

Pierwszym etapem, od którego zaczęto zbieranie badań, było stworzenie wstępnego kwestionariusza pytań. Zabieg ten pomógł stwierdzić po pierwszych odpowiedziach, jakie błędy zostały popełnione przy formułowaniu ankiety. Po analizie próbki do przeprowadzania wywiadów i wysyłania ankiet on-line wykorzystano kwestionariusz składający się w ostateczności z 14 pytań:

1. Płeć.

2. Wiek.

3. W jakiego rodzaju dyscyplinie wiedzy Pan/i się specjalizuje?

4. Co rozumie Pan/i przez pojęcie „dokument elektroniczny”?

5. Czy wytwarza Pan/i dokumentację elektroniczną?

6. Jakiego rodzaju spraw dotyczy wytwarzana dokumentacja elektroniczna?

7. W jakim formacie jest przechowywana?

8. Czy segreguje Pan/i tę dokumentacje?

9. Jaka jest struktura danych?

10. Jak wyszukuje Pan/i dokumenty elektroniczne?

11. Jak chroni Pan/i swoją dokumentację przed zmianami?

12. Czy digitalizuje Pan/i dokumentację tradycyjną?

13. Jak duży jest Pana/i zasób?

14. Jaki ma Pan/i stosunek do dokumentacji papierowej, a jaki do elektronicznej? 
Badania przeprowadzono na grupie 285 osób. Z tej liczby zwrotnych ankiet, łącznie z przeprowadzonymi wywiadami uzyskano 62 odpowiedzi.

Pytanie pierwsze dotyczyło płci. Podczas prowadzenia badań zauważono, że mężczyźni wykazywali większą chęć odpowiadania na ankiety. Ze względu na to zwiększono liczbę wysyłanych ankiet, zawężając jednorazowo grupę odbiorców do samych kobiet. Wynikiem tego zabiegu było zrównoważenie liczby odpowiedzi od ankietowanych kobiet i mężczyzn (tab. 1).

Tab. 1. Podział respondentów według płci

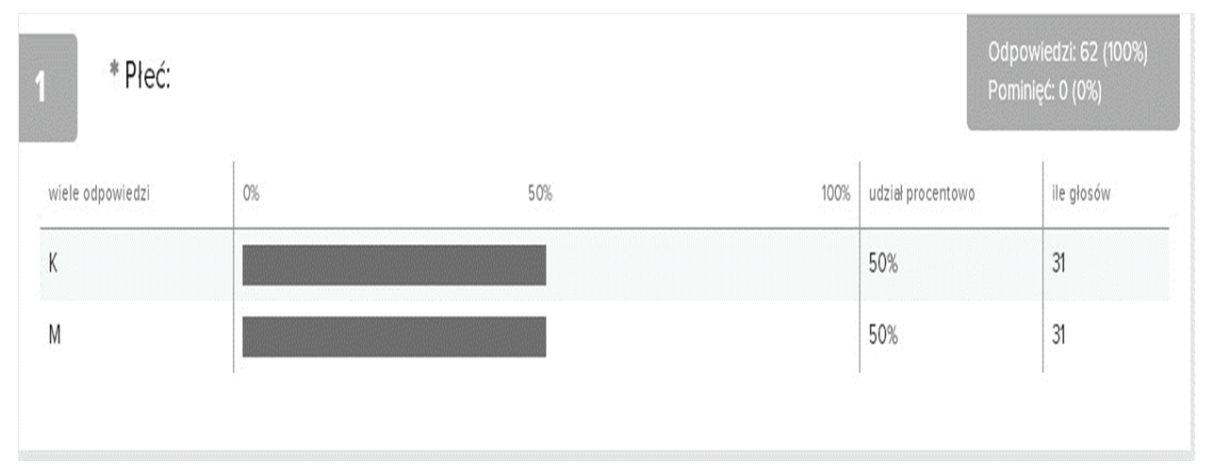

Pytanie drugie odnosiło się do wieku ankietowanych. Za wiek początkowy przyjęto 25 rok życia, biorąc pod uwagę fakt, iż najmłodszy pracownik naukowy będzie tuż po studiach magisterskich. Kwestionariusz posiadał możliwość podania innego wieku w razie, gdyby możliwości wyboru podane w tabeli okazały się niewystarczające. Jako przedział wiekowy przyjęto 10 lat (tab. 2). 
Tab. 2. Wiek osób odpowiadających

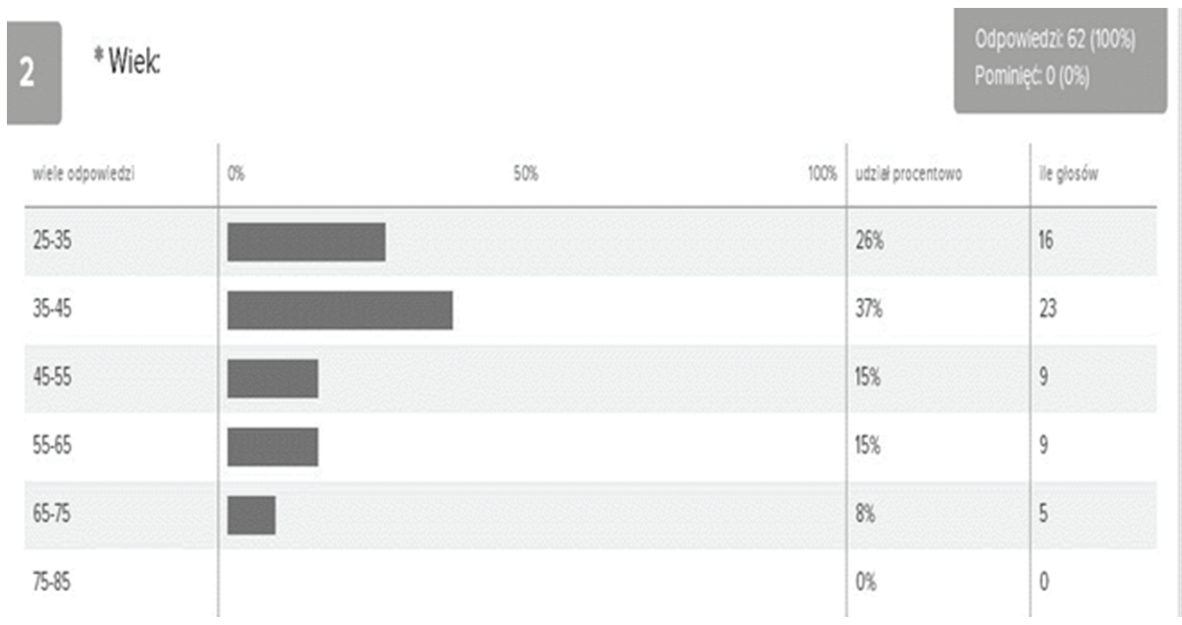

Pytanie trzecie dotyczyło dyscypliny wiedzy, jaką zajmują się ankietowani. Okazało się bardzo pomocne. Zauważono, że dyscyplina wiedzy wpływa na sposób pojmowania dokumentu elektronicznego, np. mężczyźni, którzy w pytaniu dotyczącym dyscypliny wiedzy wpisywali „fizyka”, za każdym razem mówiąc o dokumencie elektronicznym, pisali o pliku, czego w przypadku innych dyscyplin nie dało się zaobserwować.

Ankiety rozsyłano drogą elektroniczną do pracowników naukowych pracujących na wszystkich wydziałach UMK znajdujących się w Toruniu. Były to wydziały:

- Biologii i Ochrony Środowiska,

- Chemii,

- Filologiczny,

- Fizyki, Astronomii i Informatyki Stosowanej,

- Humanistyczny,

- Matematyki i Informatyki,

- Nauk Ekonomicznych i Zarządzania,

- Nauk Historycznych,

- Nauk o Zdrowiu,

- Nauk o Ziemi,

- Nauk Pedagogicznych,

- Politologii i Studiów Międzynarodowych,

- Prawa i Administracji, 
- Sztuk Pięknych,

- Teologiczny.

Po przeanalizowaniu odpowiedzi stworzono ilościową listę osób wraz z udziałem procentowym i dyscypliną wiedzy, w jakiej się specjalizowały.

W jakiego rodzaju dyscyplinie wiedzy Pan/i się specjalizuje?

Odpowiedziało:

- 9 osób archiwistyka - 15\%,

- 8 osób historia sztuki, nauka o sztuce - 13\%,

- 7 osób chemia - $11 \%$,

- 6 osób biologia, biofizyka, biologia molekularna, mikrobiologia - 10\%,

- 5 osób prawo, prawo giełdowe, prawo międzynarodowe, prawo wyborcze $-8 \%$,

- 4 osoby ekonomia, zarządzanie, finanse $-6 \%$,

- 4 osoby filologia angielska, językoznawstwo - 6\%,

- 4 osoby geografia, nauka o ziemi $-6 \%$,

- 3 osoby fizyka, astronomia $-5 \%$,

- 2 osoby humanistyka $-3 \%$,

- 2 osoby pedagogika $-3 \%$,

-2 osoby socjologia $-3 \%$,

- 1 osoba archeologia $-2 \%$,

- 1 osoba etnologia - $2 \%$,

- 1 osoba geologia $-2 \%$,

- 1 osoba historia $-2 \%$,

- 1 osoba konserwacja $-2 \%$,

- 1 osoba matematyka $-2 \%$.

Kolejne zagadnienie dotyczy definicji dokumentu elektronicznego. Po przeanalizowaniu odpowiedzi główna refleksja, jaka się nasuwa, zawierała się w stwierdzeniu, że według respondentów dokument elektroniczny postrzegany jako dokument cyfrowy zastępujący wersję papierową. Najbardziej osobliwą odpowiedzią na to pytanie było utożsamienie dokumentu elektronicznego z plikiem .pdf, z równoczesnym wyłączeniem z tej definicji pozostałych formatów. Taka odpowiedź padła tylko raz. Pozostałe odpowiedzi brzmiały dość podobnie: „Materiały, które są tworzone w komputerze”; „Dokument w formie dowolnego pliku, zapisanego na dysku komputera lub na serwerze”; „Dokument przygotowany na komputerze w postaci pliku". 
Można zatem zauważyć, że respondentom nie jest znana definicja dokumentu elektronicznego. Generalnie dominuje przeświadczenie, że jest to plik zapisany cyfrowo, podczas gdy zgodnie z zapisami Ustawy z dnia 17 II 2005 r. o informatyzacji działalności podmiotów realizujących zadania publiczne, dokument elektroniczny został zdefiniowany jako „stanowiący odrębną całość znaczeniową zbiór danych uporządkowanych w określonej strukturze wewnętrznej i zapisany na informatycznym nośniku danych"1. Najbardziej zbliżoną do tej definicji była odpowiedź kobiety, w przedziale wiekowym 65-75 lat, specjalizującej się w chemii:

Za dokument elektroniczny uważam plik tekstowy, muzyczny, graficzny, filmowy oraz plik, będący kombinacją poprzednio wymienionych, które uzyskujemy przy zastosowaniu odpowiedniego programu komputerowego, zapisujemy na komputerze, aby można go w każdej chwili odtworzyć.

Na podstawie 62 odpowiedzi stworzono listę cech, które ma dokument elektroniczny. Wg osób biorących udział są takie 4. Musi on:

- być zapisany w formie elektronicznej,

- powstać na urządzeniu elektronicznym,

- być odczytywany i przechowywany w formie cyfrowej,

- być stworzony przy użyciu programu komputerowego.

Kolejną nurtującą kwestią było pytanie dotyczące wytwarzania dokumentacji elektronicznej przez pracowników naukowych. Na to pytanie $100 \%$ odpowiedziało twierdząco. To bardzo dobry wynik.

Pytanie szóste odnosi się do rodzaju spraw, których dotyczy wywarzana dokumentacja elektroniczna. Głównie obejmuje sprawy służbowe: wszelkie badania naukowe, materiały dydaktyczne, teksty publikacji, projekty oraz prezentacje. Niewielki procent respondentów odpowiedział, że w tej formie wytwarza również dokumentację prywatną.

Kolejne pytanie dotyczy formatu, w jakim ankietowani przechowują swoją dokumentację elektroniczną (tab. 3).

${ }^{1}$ Ustawa z dnia 17 lutego 2005 r. o informatyzacji działalności podmiotów realizujących zadania publiczne, Dz.U. 2005, nr 64, poz. 565 z późn. zm. 
Tab. 3. Rodzaje formatów przechowywanej dokumentacji elektronicznej

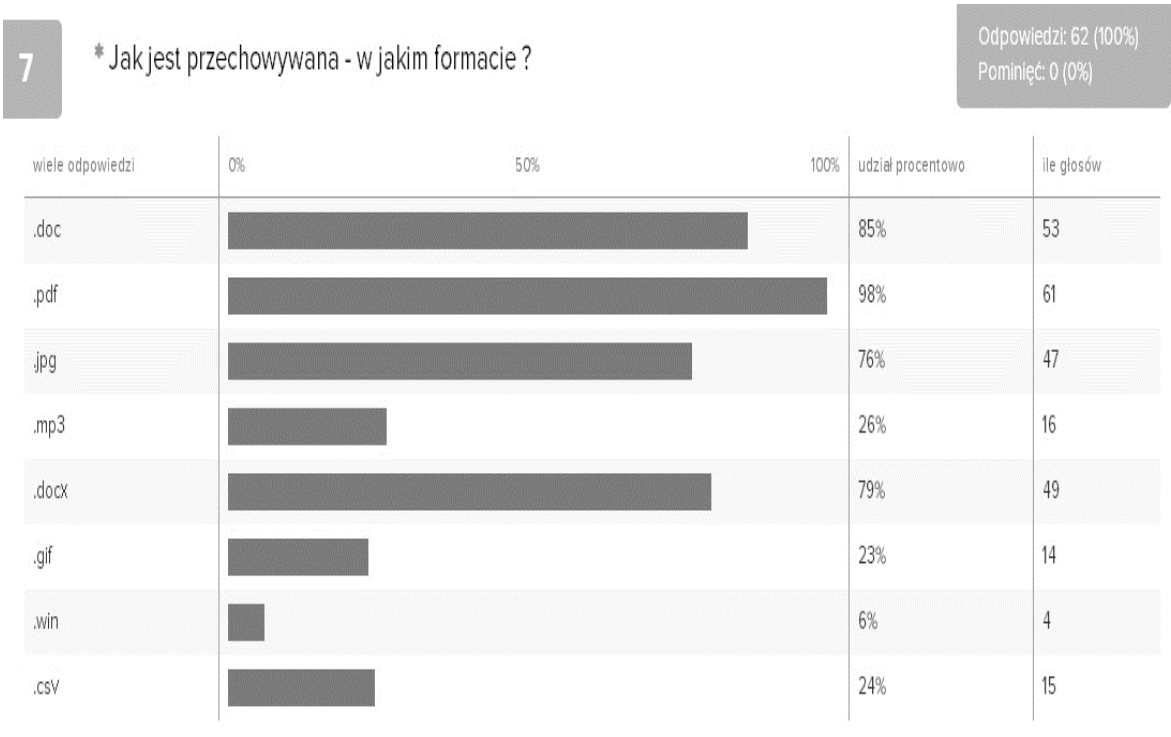

Kwestionariusz dawał możliwość wpisania dodatkowych formatów, z czego respondenci chętnie korzystali. Poza wskazanymi ankietowani używają oprogramowania zapisującego dokumenty w plikach z rozszerzeniami: .odt, .tiff, .xppt, .txt, .bmp, .rtf, .xls, .avi, .mp4, .ppt, .pptx, .ps, .eps, .pcx.

Kolejny aspekt dotyczy segregacji dokumentacji elektronicznej. Na 62 odpowiadających tylko dwie osoby udzieliły odpowiedzi, że nie mają uporządkowanej dokumentacji.

Pytanie dziewiąte odnosiło się do struktury danych. Liczna grupa osób odpowiedziała, że tworzy wielostopniowe katalogi i foldery. Jedna osoba odpowiedziała, że układa dokumentację ze względu na obszar, którego dotyczy. Bardzo często zdarzały się odpowiedzi wskazujące na segregowanie materiałów hierarchicznie, dziedzinowo, alfabetycznie, a niekiedy według daty i tematu (czyli chronologicznie bądź tematycznie).

Na pytanie dziesiąte dotyczące wyszukiwania swoich dokumentów elektronicznych, respondenci odpowiadali, że wyszukują je, korzystając w tym celu z nadanej przez siebie struktury, alfabetycznie, według układu, dziedzin, nazw i czasu utworzenia pliku bądź za pomocą wyszukiwarki systemowej.

Jeden z respondentów przyznał się, że stworzył bibliografię, w której każdy artykuł ma odpowiednią liczbę porządkową odpowiadającą nazwie pliku PDF. 
Jest to bardzo ciekawe zjawisko, wprowadza duży porządek oraz prawdopodobnie pomaga w wyszukiwaniu plików.

Kolejne pytanie dotyczyło ochrony dokumentacji przed zmianami. Generalnie większość odpowiedzi mówiła o oznaczaniu ostatniej wersji jednego pliku i usuwaniu pozostałych. Często też respondenci wspominali, że numerują kolejne wersje. Z licznych odpowiedzi wynika, że wszystko zależy od ważności dokumentu. Jeżeli dokument jest istotny, wtedy wrzuca się go do konkretnego folderu, zapisuje na nośniku, a ponadto przechowuje go na serwerze. Natomiast jeśli dokument jest mniej ważny, wtedy zostawia się wyłącznie ostatnią postać dokumentu w jednym miejscu na dysku komputera.

Następna pytanie odnosiło się do digitalizacji dokumentacji tradycyjnej. Analizując odpowiedzi zauważymy, że większość osób stara się skanować materiały. Najczęściej są to dokumenty z epoki „sprzed komputera”. Dzieje się tak w przypadku tylko ważnych materiałów takich jak: dyplomy, umowy czy wyniki badań. Tylko jedna osoba stwierdziła, że skanuje wyłącznie dokumentację prywatną bez materiałów naukowych.

Czy digitalizuje Pan/i dokumentację tradycyjną?

Odpowiedziało:

- tak 24 osoby $-39 \%$,

- nie 19 osób - 31\%,

- rzadko, czasami - 18 osób - 29\%.

Pytanie trzynaste dotyczyło wielkości zasobu dokumentacji elektronicznej każdego z pracowników naukowych. Ciekawym zjawiskiem jest fakt, że niektórzy z respondentów potrafili podać dokładną wartość swojego zasobu. Niestety najczęściej odpowiadano, że dokumentacja jest przechowywana na różnego rodzaju pendrive'ach, płytach czy nawet dyskietkach i ciężko jest to oszacować. Wśród ankietowanych największy zasób posiadał respondent z 3 komputerami, 4 dyskami zewnętrznymi, 7 pendrive'ami i setkami płyt. Jego zasób z samych komputerów sięgał około 4,5 TB. Respondent ten zajmuje się filologią angielską, a przede wszystkim przekładoznawstwem, co w pewnym sensie tłumaczy ogromny zbiór.

Ostatnie, czternaste pytanie dotyczyło stosunku odpowiadających do dokumentacji tradycyjnej i elektronicznej. Większość z odpowiadających uważa, że dokumentacja papierowa jest cenniejsza od elektronicznej. Ponadto jest trwalsza, lepiej się ją czyta i łatwiej można poprawiać na niej ewentualne 
błędy. Jest także zdecydowanie bardziej odporna na zmiany technologiczne. Niestety zabiera dużo miejsca. Natomiast dokumentacja elektroniczna zabiera mniej miejsca, wygodniej się przechowuje, a ponadto można z niej korzystać w dowolnym miejscu. Dodatkowo można ją udostępniać innym w łatwy i szybki sposób. Praca z tą dokumentacją jest zdecydowanie sprawniejsza niż z wielotomowymi książkami. Jednak ten rodzaj dokumentacji wymaga ciągłej troski i pielęgnacji.

Spuścizny wytwarzane przez pracowników naukowych po rewolucji komputerowej to przyszłość. Na podstawie przedstawionych ankiet można zauważyć, że respondenci nie spychają na margines dokumentacji elektronicznej. Wręcz przeciwnie, niektórzy są zdolni szybciej odrzucić dokumentację tradycyjną niż elektroniczną, która już obecnie towarzyszy im na co dzień.

Warto zwrócić uwagę na fakt, że im osoby są młodsze, tym zdecydowanie rzadziej posiadają papierowe wersje swoich dokumentów. Drukują je wyłącznie wtedy, gdy wymagają tego zewnętrzne okoliczności. Tym ważniejsze jest zachowanie elektronicznej części spuścizny. Problem tkwi teraz w archiwach. Jeżeli archiwa nadal będą unikały tej dokumentacji, to co w takim razie zostanie $\mathrm{z}$ aktualnie tworzonych spuścizn?

\section{- Przepisy prawne}

Ustawa z dnia 17 lutego 2005 r. o informatyzacji działalności podmiotów realizujących zadania publiczne, Dz.U. 2005, nr 64, poz. 565 z późn. zm.

\section{Summary}

Growing electronic documents created by researchers

In the contemporary world technology is an indispensable element, both in personal and professional sphere. Despite the fact, that we do not attach significance to it in our everyday lives, the technological development engulfed us and still reminds us about that. In the face of dynamically growing digitization there occurred a new form of document - an electronic document. The study concerns the growing electronic documentation among researchers working at the Nicolaus Copernicus University in Torun. The analysis of surveys and interviews resulted in thesis, that researchers use e-document more frequently than analog documentation. Flexibility and accessibility of this type of documents become a problem in personal papers which will be archived in the future - maybe in most part in the form of electronic documentation. 
